\title{
Handout Bioteknologi SMK "Pemanfaatan Dami Nangka sebagai Bahan Dasar Pembuatan Nata" Meningkatkan Kemampuan Berpikir Kreatif Siswa
}

\author{
Galina Istiqhfarini ${ }^{1}$, Utami Sri Hastuti ${ }^{1}$, Dwi Listyorini ${ }^{1}$ \\ ${ }^{1}$ Pendidikan Biologi-Universitas Negeri Malang
}

\begin{tabular}{l}
\hline INFO ARTIKEL \\
\hline Riwayat Artikel: \\
Diterima: 25-01-2019 \\
Disetujui: 11-09-2019 \\
\hline
\end{tabular}

\section{Kata kunci:}

handouts; biotechnology; creative thinking; handout;

bioteknologi;

berpikir kreatif

\author{
Alamat Korespondensi: \\ Galina Istiqhfarini \\ Pendidikan Biologi \\ Universitas Negeri Malang \\ Jalan Semarang 5 Malang \\ E-mail: galina26raga@gmail.com
}

\begin{abstract}
ABSTRAK
Abstract: Learning is expected to provide learning experiences to students in order to understand learning material. The contextuality of learning resources and learning media must be improved. Biotechnology Handout "Utilization of Jackfruit Dami as the Baseline for Making Nata" is used to guide students to use learning media. This study aims to determine the effect of handouts on the ability to think creatively. This research is a quasiexperimental design with the pretest-posttest control group design method, using one control class and one treatment class as the research sample. Data analysis uses gain score and independent t-test. Based on the t-test, the Sig value is obtained. 2-tailed $(0,000)$ $<0.05$. The results of the study prove that the use of handouts can improve students' creative thinking skills.
\end{abstract}

\begin{abstract}
Abstrak: Suatu pembelajaran diharapkan memberikan pengalaman belajar kepada siswa agar dapat memahami materi pembelajaran. Konstekstualitas sumber belajar dan media pembelajaran harus ditingkatkan. Handout Bioteknologi "Pemanfaatan Dami Nangka sebagai Bahan Dasar Pembuatan Nata" digunakan untuk menuntun siswa menggunakan media pembelajaran. Tujuan penelitian ini yaitu mengetahui pengaruh handout terhadap kemampuan berpikir kreatif. Penelitian ini merupakan penelitian Quasi-eksperimental design dengan metode pretest-postest control group design menggunakan satu kelas kontrol dan satu kelas perlakuan sebagai sampel penelitian. Analisis data menggunakan gain score dan uji-t independen Berdasarkan uji-t diperoleh nilai Sig. 2-tailed $(0,000)<$ 0,05 . Hasil penelitian membuktikan bahwa penggunaan handout dapat meningkatkan kemampuan berpikir kreatif siswa.
\end{abstract}

Sekolah Menengah Kejuruan adalah pendidikan formal kejuruan yang bergerak dalam bidang keahlian tertentu (Sidiknas, 2003) dimana lulusannya diharapkan mampu menghasilkan karya kreatif dengan memanfaatkan lingkungan secara produktif sehingga siap bekerja mandiri atau mengisi lowongan pekerjaan yang telah ada (Permendikbud, 2013, 2016; Permendiknas, 2006; Premono, 2010). Kemampuan berpikir kreatif adalah kemampuan yang dimiliki seseorang dalam menggunakan pemikirannya untuk menemukan ide-ide baru, kemungkinan baru, dan penemuan baru berdasarkan tingkat originalitas dari produk yang dihasilkan (Daud, Omar, Turiman, \& Osman, 2012) serta mampu menemukan lebih dari satu jawaban terhadap suatu masalah dimana jawaban yang ditemukan tidak sembarangan, tetapi lebih ditekankan pada kuantitas, ketepatgunaan, dan keragaman jawaban berdasarkan informasi yang ada (Greenstain, 2012; Munandar, 1999). Ciri-ciri kemampuan berpikir kreatif secara kognitif dapat dilihat dari aspek keingintahuan (curiosity), kemahiran (fluency), berpikir luwes (flexibel), keaslian (orisinality), merinci (elaboration), dan berimajinasi (imagination) (Greenstain, 2012). Kemampuan berpikir kreatif dipengaruhi oleh beberapa faktor, antara lain faktor pendukung (kecerdasan, pengetahuan, gaya berikir, personaliti atau kepribadian, dan motivasi) (Buntat, Nasir, \& Sharliana, 2011) dan faktor penghambat (kendala dari rumah yaitu paksaan dari orang tua dan kendala dari sekolah yaitu sikap guru dan metode pembelajaran yang diterapkan) (Munandar, 1999).

Dalam kegiatan pembelajaran, sekolah memiliki tujuan utama yaitu mengajarkan siswa tentang cara belajar bukan hanya mentransfer pengetahuan dari pendidik ke peserta didik (Warr \& Downing, 2000). Adapun pengertian belajar yaitu memahami sesuatu, menafsirkan berdasarkan kenyataan yang terjadi, dan mampu berpikir secara abstrak (Dikmenli \& Cardak, 2010). Sehubungan dengan upaya mencetak lulusan yang kreatif, maka guru harus membekali siswa dengan pengalaman belajar melalui aktivitas belajar yang kreatif (Krayukhina, Shmakova, Smetanina, Nikolaeva, \& Tershukova, 2016). Suatu model pembelajaran untuk meningkatkan aktivitas belajar yang kreatif ialah Guided Discovery Learning. Guided Discovery Learning dapat dilakukan 
untuk mengajarkan konsep dan hubungan antar konsep (Jacobsen, Eggen, \& Kauchak, 2009) dengan cara memberikan permasalahan yang menuntun siswa agar mampu mencari penyelesaian dari permasalahan tersebut dengan petunjuk dan arahan dari guru. Dalam model pembelajaran ini dapat digunakan metode praktikum yang merupakan suatu metode pembelajaran yang menyajikan pengalaman dan dunia nyata kepada siswa untuk dapat membangun pengetahuannya sendiri (Berns \& Erickson, 2001; Komalasari, 2014) sehingga siswa lebih mampu berpikir kritis, kreatif dan inovatif (Greenstain, 2012). Kegiatan pembelajaran berupa praktikum memerlukan media kontekstual berupa alat dan bahan yang terdapat di lingkungan sekitar siswa, sedangkan bahan ajar dibutuhkan untuk menuntun siswa dalam menggunakan media pembelajaran. Bahan ajar merupakan kumpulan materi yang disusun secara sistematis yang memiliki fungsi, yaitu (1) membantu guru dalam proses pembelajaran; (2) sebagai sumber informasi untuk mempermudah siswa memahami konsep-konsep dan keterampilan yang dipelajarinya sehingga mampu mempraktekkan dan mengaplikasikan sains dalam kehidupannya (Depdiknas, 2010); (2) digunakan sebagai alat untuk mencapai target kurikulum (Depdiknas, 2010; Smith \& Jacobs, 2003).

Handout merupakan salah satu contoh bahan ajar selain buku, modul, poster, lembar kerja, wallchart, foto atau gambar, dan leaflet (Depdiknas, 2010) yang mengandung konsep penting dari suatu materi pembelajaran secara lengkap (Ah-Sanaky, 2011) dan bersifat spesifik pada satu topik tertentu sesuai dengan kebutuhan (Johnson, Martin, Brooks-Gunn, \& Petrill, 2008). Handout yang baik dapat meningkatkan pemahaman konsep (Wulandari, 2016), hasil belajar kognitif, dan motivasi siswa dalam kerja kelompok (Muliawati, 2015), serta dapat menuntun siswa mengaplikasikan pengetahuannya dalam kehidupan sehari-hari sebagai bekal hidup di masa mendatang (Sakraida \& Draus, 2005). Dalam usaha mencapai tujuan pembelajaran, guru harus mampu mengembangkan bahan ajar sesuai kebutuhan siswa (Permendiknas, 2007; Sakraida \& Draus, 2005). Pemanfaatan lingkungan sekitar siswa dan hasil penelitian yang sesuai dengan kebutuhan siswa dapat dikembangkan untuk materi handout Handout yang dikembangkan berdasarkan hasil penelitian memuat materi utama, dilengkapi dengan petunjuk praktikum untuk memberikan pengalaman belajar pada siswa, serta tugas terstruktur untuk melatih siswa merancang suatu penelitian sederhana sesuai materi yang diajarkan sehingga dapat melatih siswa menyajikan suatu ide dengan cara yang berbeda. Kemampuan menyajikan suatu ide dengan cara yang berbeda merupakan salah satu ciri kemampuan berpikir kreatif (Munandar, 1999). Ide tersebut akan dituangkan dalam tugas terstruktur yang merupakan bagian dari handout.

Salah satu materi pembelajaran yang secara langsung dapat memanfaatkan lingkungan yaitu Bioteknologi. Berdasarkan hasil wawancara dan angket analisis kebutuhan pada SMK Al-Basthi Kecamatan (Nata de Dami), dalam upaya pemanfaatan limbah buah nangka yang mencemari lingkungan di sekitar sekolah. Hal tersebut merupakan salah satu langkah kreatif dalam memecahkan masalah lingkungan. Pengantenan kabupaten Pamekasan, selama ini materi Bioteknologi dianggap sulit oleh siswa karena mereka tidak pernah mendapat kesempatan melakukan praktikum. Siswa kurang memahami konsep yang dipelajari sehingga kemampuan berpikir kreatif siswa dalam menerapkan konsep Bioteknologi sangat rendah. Siswa belum mampu menghasilkan karya-karya kreatif dalam bidang Bioteknologi. Hal ini disebabkan oleh proses pembelajaran yang hanya studi literatur, teacher center dan tidak dilakukan kegiatan praktikum, padahal materi Bioteknologi konvensional dapat dipraktikumkan, salah satunya yaitu pembuatan nata dari dami nangka.

\section{METODE}

Penelitian ini adalah penelitian Quasi-eksperimental design melalui metode pretest-postest control group design untuk mengetahui keefektifan handout terhadap kemampuan berpikir kreatif siswa. Hipotesis penelitian ini ialah terdapat perbedaan yang signifikan antara peningkatan kemampuan berpikir kreatif siswa pada kelas kontrol dan kelas perlakuan. Handout yang digunakan telah divalidasi. Hasil validasi ahli materi Mikrobiologi didapatkan sebesar 91,67\% dan validasi ahli media pembelajaran sebesar 96,67\%, menunjukkan bahwa handout yang dikembangkan sangat valid/layak walaupun perlu sedikit revisi. Adapun hasil uji keterbacaan oleh praktisi lapangan, yaitu seorang guru dan 20 orang siswa, didapatkan nilai rerata sebesar 95,32\%, menunjukkan bahwa handout sangat layak digunakan. Subjek penelitian ialah siswa SMK Al-Basthi kelas XII sebanyak 40 siswa yang terbagi menjadi dua kelas, yaitu kelas kontrol dan kelas perlakuan. Teknik pengumpulan data kemampuan berpikir kreatif siswa menggunakan tes tulis (pretes-postes) dengan soal uraian dan rubrik penilaian kemampuan berpikir kreatif. Uji homogenitas dan uji normalitas dilakukan terhadap nilai pretes. Data dianalisis secara kuantitatif menggunakan gain score, kemudian data dianalisis menggunakan uji t tidak berpasangan dengan kriteria pengujian $\mathrm{H} 1$ diterima jika $\mathrm{t}$ hitung $>\mathrm{t}$ tabel dengan menggunakan taraf kepercayaan 0,05.

\section{HASIL}

Data hasil uji homogenitas dan normalitas menunjukkan bahwa data bersifat homogen dan terdistribusi normal. Data nilai ketuntasan klasikal kemampuan berpikir kreatif siswa kelas kontrol dan kelas perlakuan terlihat pada tabel 1. Berdasarkan gain score terlihat bahwa terjadi peningkatan kemampuan berpikir kreatif siswa baik pada kelas kontrol maupun kelas perlakuan dimana peningkatan kemampuan berpikir kreatif kelas perlakuan lebih tinggi daripada kelas kontrol. Hasil analisis data dengan uji t tidak berpasangan menunjukkan bahwa hipotesis penelitian diterima, berarti ada perbedaan yang signifikan antara 
peningkatan kemampuan berpikir kreatif siswa pada kelas kontrol dan kelas perlakuan dengan nilai sig ( 2 -tailed) $0,000<0,05$ (tabel 2).

Tabel 1. Nilai Kemampuan Berpikir Kreatif Siswa

\begin{tabular}{cccc}
\hline Kelas & Pretes & Postes & Gain score \\
\hline Kontrol & 45 & 61 & 16 \\
Perlakuan & 45 & 83 & 38 \\
\hline
\end{tabular}

Tabel 2. Hasil uji t berpasangan

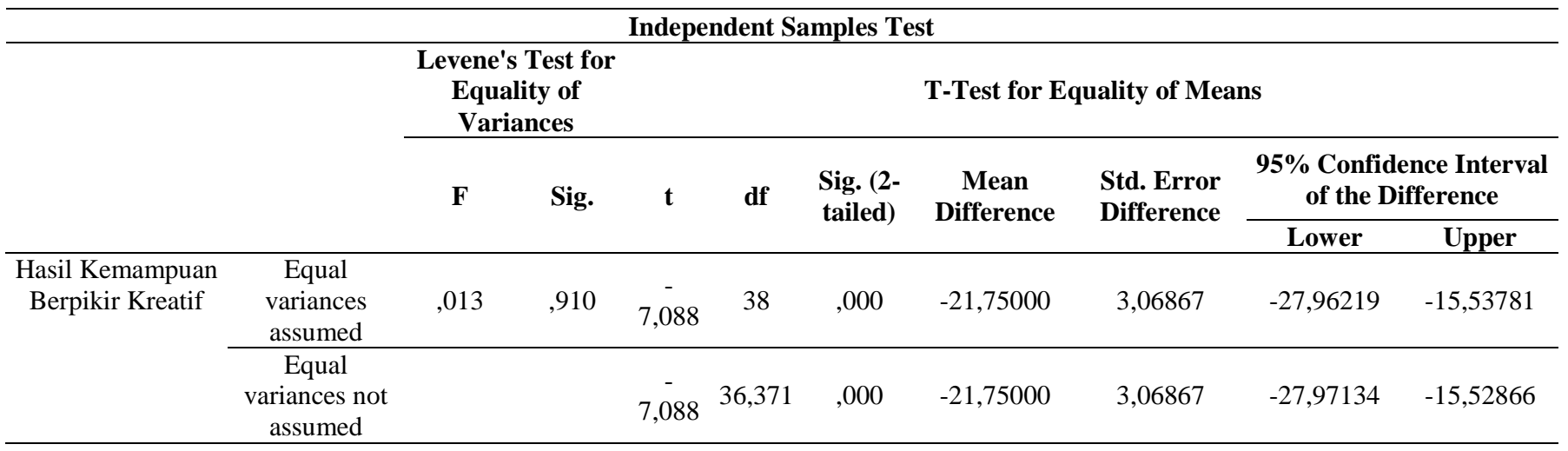

Peningkatan skor kemampuan berpikir kreatif siswa terjadi pada setiap aspek kemampuan berpikir kreatif, yaitu pada aspek keingintahuan, kemahiran, berpikir luwes, keaslian, merinci, dan imajinasi setelah mengikuti proses pembelajaran baik pada kelas kontrol maupun pada kelas perlakuan. Hasil rerata gain score tiap aspek kemampuan berpikir kreatif siswa terlihat pada tabel 3.

Tabel 3. Rerata Gain Score Setiap Aspek Kemampuan Berpikir Kreatif siswa

\begin{tabular}{lcccccc}
\hline \multirow{2}{*}{ Kelas } & \multicolumn{5}{c}{ Rerata Gain Score Aspek Kemampuan Berpikir Kreatif } \\
\cline { 2 - 7 } & Keingintahuan & Kemahiran & Berpikir Luwes & Keaslian & Merinci & Imajinasi \\
\hline Kontrol & 0,70 & 1,55 & 0,20 & 0,05 & 1,05 & 0,35 \\
Perlakuan & 0,80 & 1,80 & 1,25 & 1,15 & 1,65 & 2,40 \\
Selisih & 0,10 & 0,25 & 1,05 & 1,10 & 0,60 & 2,05 \\
\hline
\end{tabular}

Berdasarkan hasil uji-t tidak berpasangan terhadap gain skor untuk setiap aspek kemampuan berpikir siswa, didapatkan hasil bahwa terdapat perbedaan yang signifikan antara peningkatan kemampuan berpikir luwes, keaslian, dan imajinasi ada kelas kontrol dan kelas perlakuan, dimana pada kelas perlakuan terjadi peningkatan yang lebih tinggi dari pada kelas kontrol. Rekap hasil uji-t tidak berpasangan terhadap gain skor untuk setiap aspek terlihat pada tabel 4 .

Tabel 4. Rekap Hasil uji-t Tidak Berpasangan pada Setiap Aspek Kemampuan Berpikir Kreatif

\begin{tabular}{lccl}
\hline \multicolumn{1}{c}{ Aspek } & t & Sig. (2-tailed) & \multicolumn{1}{c}{ Simpulan } \\
\hline Keingintahuan & $-0,372$ & 0,712 & Tidak signifikan \\
Kemahiran & $-1,144$ & 0,260 & Tidak signifikan \\
Berpikir luwes & $-3,566$ & 0,001 & Signifikan \\
Keaslian & $-4,423$ & 0,000 & Signifikan \\
Merinci & $-1,910$ & 0,064 & Tidak signifikan \\
Imajinasi & $-9,085$ & 0,000 & Signifikan \\
\hline
\end{tabular}




\section{PEMBAHASAN}

Handout yang dikembangkan dalam penelitian ini berisi materi bioteknologi konvensional pembuatan Nata de Dami berdasarkan hasil penelitian, petunjuk praktikum, soal-soal evaluasi, dan tugas terstruktur. Pada penelitian ini terbukti bahwa penggunaan handout dalam pembelajaran pada topik bioteknologi konvensional meningkatkan kemampuan berpikir kreatif siswa secara signifikan dari pada pembelajaran pada kelas kontrol. Hal tersebut dikarenakan materi tentang pembuatan nata de dami yang terdapat dalam handout merupakan pengetahuan baru bagi siswa. Materi ini merupakan salah satu upaya pemanfaatan potensi lokal di lingkungan sekitar siswa sehingga sesuai dengan kebutuhan siswa, karena di lingkungan sekitar siswa terdapat banyak petani dan pedagang nangka yang dapat menghasilkan dami nangka dalam jumlah banyak yang menjadi limbah tidak terpakai. Jika siswa mampu memanfaatkan dami nangka untuk bahan dasar pembuatan nata maka siswa dapat mengurangi limbah dami nangka yang dapat mencemari lingkungan. Hal ini dapat membiasakan siswa untuk berpikir kreatif dalam memecahkan suatu permasalahan lingkungan. Disamping itu, melalui kegiatan praktikum ini, siswa mampu membuat makanan olahan dari limbah bagian buah yang bergizi sehingga dapat melatih siswa menghasilkan ide-ide kreatif untuk dapat menghasilkan produk yang memiliki nilai guna yang tinggi.

Ciri-ciri kemampuan yang berpikir kreatif secara kognitif dapat dilihat dari aspek keingintahuan (curiosity), kemahiran (fluency), berpikir luwes (flexibel), keaslian (orisinality), merinci (elaboration), dan berimajinasi (imajination) (Greenstain, 2012). Salah satu upaya untuk mengetahui kemampuan berpikir kreatif siswa dapat dilakukan oleh guru melalui penilaian terhadap setiap aspek tersebut setelah melakukan proses pembelajaran. Berdasarkan hasil hasil uji-t tidak berpasangan terhadap gain skor pada setiap aspek kemampuan berpikir kreatif siswa, diketahui bahwa terhadap perbedaan yang signifikan pada aspek berpikir luwes, keaslian, dan imajinasi pada kelas kelas kontrol dan kelas perlakuan. Pada kelas perlakuan terjadi peningkatan yang lebih tinggi dari pada kelas kontrol.

Aspek berpikir luwes (fleksibel), yaitu memberikan gagasan yang variatif terhadap suatu masalah atau pertanyaan dan menyajikan suatu konsep secara berbeda, mengalami peningkatan yang signifikan. Hal ini disebabkan materi yang diangkat dalam handout tentang pemanfaatan dami nangka sebagai bahan dasar pembuatan nata merupakan alternatif suatu pemecahan masalah pencemaran lingkungan akibat penumpukan limbah dami nangka. Hal ini dapat membiasakan siswa berpikir menggunakan sudut pandang yang berbeda untuk mengatasi masalah limbah dami nangka. Disamping itu, pada kegiatan praktikum dimana terdapat alat-alat praktikum yang sulit ditemukan disekitar siswa, dapat mengarahkan siswa untuk berpikir lebih luwes dalam mencari alat alternatif yang memiliki fungsi yang sama dengan alat yang tertera dalam petunjuk praktikum. Salah satu contoh adalah pengganti alat berupa autoklaf untuk proses melakukan sterilisasi ialah menggunakan panci untuk merebus air yang digunakan untuk mensterilisasikan alat-alat yang digunakan dalam praktikum.

Aspek keaslian (orisinality), yaitu gagasan yang disampaikan bersifat relatif baru dan mengandung kombinasikombinasi yang tidak lazim dalam menyelesaikan masalah atau menjawab suatu pertanyaan, mengalami peningkatan yang signifikan. Hal ini disebabkan oleh karena selain berisi materi yang pendukung untuk meningkatkan pemahaman siswa, petunjuk praktikum untuk memberikan pengalaman belajar siswa, soal-soal evaluasi untuk membantu siswa membangun pengetahuannya, terdapat pula tugas terstruktur untuk mengarahkan siswa merancang suatu penelitian sederhana sesuai dengan materi yang telah dipelajari dalam handout, sehingga dapat melatih siswa menyajikan suatu konsep secara berbeda. Kemampuan menyajikan suatu konsep secara berbeda merupakan salah satu ciri kemampuan berpikir kreatif (Munandar, 1999).

Aspek berimajinasi (imagination), yaitu mampu menemukan kebenaran suatu gagasan penyelesaian masalah, mengalami peningkatan yang signifikan. Hal ini disebabkan oleh karena pembelajaran melalui kegiatan praktikum akan memberikan pengalaman belajar bagi siswa terutama pada proses menganalisis data hasil praktikum sesuai dengan materi yang dipelajari, sehingga siswa akan terbiasa berpikir menghubungkan antara suatu hal dengan hal lain sehingga dapat menarik suatu kesimpulan. Setelah siswa melakukan praktikum pembuatan Nata de Dami, siswa akan dihadapkan pada permasalahan tentang perbedaan kualitas lapisan nata yang dihasilkan. Dengan demikian siswa akan berpikir untuk menemukan kemungkinan penyebab terjadinya perbedaan kualitas lapisan nata tersebut, menggunakan teori pendukung yang telah dipelajari dalam handout.

Aspek keingintahuan (curiosity) mengalami peningkatan tetapi tidak signifikan. Handout tentang pembuatan nata dari dami nangka merupakan hal baru bagi siswa sehingga sebelum pelajaran dimulai, terdapat banyak pertanyaan dari siswa karena rasa ingin tahu yang tinggi tentang hal tersebut baik pada kelas kontrol maupun kelas perlakuan. Hal ini disebabkan karena siswa belum memahami sepenuhnya tentang materi pembuatan nata de dami dan siswa tidak mempraktikkannya. Sementara itu, pada kelas perlakuan, siswa telah memahami materi pembuatan nata de dami dengan membaca handout dan mempraktikkannya, sehingga peningkatan rasa ingin tahu siswa tidak signifikan.

Aspek kemahiran (fluency) mengalami peningkatan yang tidak signifikan. Aspek kemahiran adalah kemampuan siswa dalam memberikan banyak jawaban terhadap suatu pertanyaan. Pertanyaan yang muncul pada soal pretes dan prostes terkait dengan perbedaan bioteknologi konvensional dan modern, sedangkan dalam proses pembelajaran pada kelas kontrol maupun kelas perlakuan, materi tersebut dijelaskan oleh guru pengajar. Jika siswa telah memahami materi dengan baik maka siswa dapat memberikan banyak jawaban terhadap suatu pertanyaan dan kemampuan berpikir kreatif siswa akan meningkat (Buntat et al., 2011). 
Aspek memperinci (elaborasi), yaitu memperkaya dan menata atau memperinci suatu gagasan sehingga lebih berkualitas, juga mengalami peningkatan yang tidak signifikan. Pertanyaan pada pretes dan prostes untuk mengukur aspek memperici berhubungan dengan manfaat serat dalam menjaga kesehatan. Materi ini dapat diperoleh tidak hanya pada pembelajaran bioteknologi, tetapi juga pada materi lain seperti sistem pencernaan manusia sehingga siswa yang telah menguasai kedua materi tersebut dapat menjawab dengan rinci pernyataan yang diajukan.

\section{SIMPULAN}

Handout Bioteknologi SMK "Pemanfaatan Dami Nangka sebagai Bahan Dasar Pembuatan Nata" mampu meningkatkan kemampuan berpikir kreatif siswa baik dalam aspek keingintahuan (curiosity), kemahiran (fluency), berpikir luwes (flexibel), keaslian (orisinality), merinci (elaboration), dan berimajinasi (imajination).

Seseorang yang memiliki kemampuan berpikir kreatif adalah seseorang yang mampu menggunakan pemikirannya untuk menemukan ide-ide baru, kemungkinan baru, dan penemuan baru berdasarkan tingkat originalitas dari produk yang dihasilkan. Oleh karena itu, suatu pembelajaran harus mampu memberikan pengalaman belajar pada siswa dalam mengggunakan pemikirannya untuk menyelesaikan suatu masalah dengan cara mengembangkan materi dan bahan ajar sesuai dengan lingkungan sekitar siswa.

\section{DAFTAR RUJUKAN}

Ah-Sanaky, H. (2011). Media Pembelajaran Buku Pegangan Wajib Guru dan Dosen. Yogyakarta: Kaukaba Dipantara.

Berns, R. G., \& Erickson, P. M. (2001). Contextual Teaching and Learning: Preparing Students for the New Economy. National Dissemination Center for Career and Technical Education.

Buntat, Y., Nasir, N. S. M., \& Sharliana, N. (2011). Faktor-Faktor yang Mendorong Kreativiti di Kalangan Pelajar Universiti Teknologi Malaysia. Journal of Educational Psychology and Counseling, 2(1), 175-208.

Daud, A. M., Omar, J., Turiman, P., \& Osman, K. (2012). Creativity in Science Education. Procedia-Social and Behavioral Sciences, 59, 467-474. https://doi.org/https://doi.org/10.1016/j.sbspro.2012.09.302

Depdiknas. (2010). Jukdis Pengembangan Bahan Ajar SMA (Departemen Pendidikan Nasional).

Dikmenli, M., \& Cardak, O. (2010). A Study on Biology Student Teachers' Conceptions of Learning. Procedia-Social and Behavioral Sciences, 2(2), 933-937. https://doi.org/https://doi.org/10.1016/j.sbspro.2010.03.129

Greenstain, L. (2012). Assesing 21 th Century Skills. Library of Congress Cataloging-in-Publication Data.

Jacobsen, D. A., Eggen, P., \& Kauchak, D. (2009). Methods for Teaching Metode-Metode Pengajaran Meningkatkan Belajar Siswa TK-SMA. Yogyakarta: Pustaka Pelajar.

Johnson, A. D., Martin, A., Brooks-Gunn, J., \& Petrill, S. A. (2008). Order in the House! Associations among Household Chaos, the Home Literacy Environment, Maternal Reading Ability, and Children's Early Reading. Merrill-Palmer Quarterly (Wayne State University. Press), 54(4), 445.

Krayukhina, O. E., Shmakova, L. E., Smetanina, V. Y., Nikolaeva, E. A., \& Tershukova, M. B. (2016). Activation of Learning and Creative Activity of the Vocational Pedagogical University Students. International Journal of Environmental and Science Education, 11(15), 8311-8322.

Muliawati, D. I. (2015). Pengembangan Handout Berbasis Team Assisted Individualization (TAI) untuk Meningkatkan Prestasi Belajar Siswa pada Materi Pembuatan Etanol Skala Laboratorium SMK Kimia Industri. Universitas Sebelas Maret.

Munandar, S. C. (1999). Mengembangkan Bakat dan Kreativitas Anak Sekolah, Penuntun bagi Guru dan Orangtua. Jakarta: PT Gramedia Widiasarana Indonesia.

Permendikbud. (2013). Kerangka Dasar dan Struktur Kurikulum Sekolah Menengah Kejuruan/Madrasah Aliyah Kejuruan (Peraturan Menteri Pendidikan dan Kebudayaan Republik Indonesia Nomor 70 Tahun 2013).

Permendikbud. (2016). Standar Kompetensi Lulusan (Peraturan Menteri Pendidikan dan Kebudayaan Republik Indonesia Nomor 20 Tahun 2016).

Permendiknas. (2007). Standar Kualifikasi Akademik dan Kompetensi Guru (Permendiknas Nomor 16 Tahun 2007).

Premono, A. (2010). Kompetensi Keahlian Sekolah Menengah Kejuruan: Antara Kebijakan dan Realita. Jurnal Pendidikan Penabur, 9(15), 51-61.

Sakraida, T. J., \& Draus, P. J. (2005). Quality Handout Development and Use. Journal of Nursing Education, 44(7), 326.

Smith, B. D., \& Jacobs, D. C. (2003). TextRev: A Window into How General and Organic Chemistry Students Use Textbook Resources. Journal of Chemical Education, 80(1), 99.

Warr, P., \& Downing, J. (2000). Learning Strategies, Learning Anxiety and Knowledge Acquisition. British Journal of Psychology, 91(3), 311-333.

Wulandari, A. (2016). Pengembangan Bahan Ajar Unsur Golongan 15 Berbasis Kontekstual untuk Matakuliah Kimia Anorganik. 